Ankara Ecz. Fak. Mec.

13. $48(1983)$
J. Fac. Pharm Ankara

13. 48 (1983)

\title{
Simetidin'in Nükleer Manyetik Rezonans Spektroskopisi ile Yeni Bir Miktar Tayini Yöntemi
}

\author{
A New Quantitative Determination of Cimetidine By \\ Nuclear Magnetic Resonance Spectroscopy
}

Tuncel ÖZDEN* Seçkin ÖZDEN* İsmail YALÇIN* Ningur NOYANALPAN*

Daha önceki çalışmalarımızda Nükleer Manyetik Rezonans Spektroskopisi yöntemi ile ilaç miktar tayinlerine çeşitli örnekler verilmişti (1-3). Bu çalışmada da, simetidin'in Nükleer Manyetik Rezonans Spektroskopisi ile miktar tayini için yeni bir yöntem ve yöntemin piyasada satılan tablet formlarına uygulanışı verilmektedir.

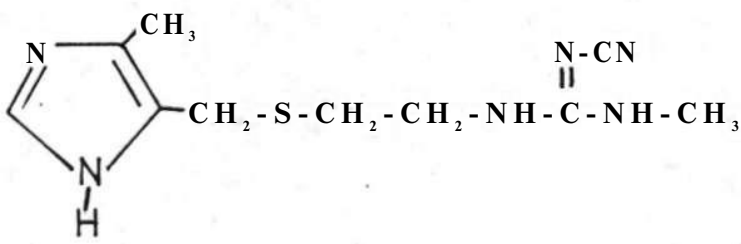

Simetidin

N-Siyao-N'-metil-N"- [ 2- [ [(5-rnetil-1H-imidazol-4-il)metil] tiyo] etil guanidin]

Güçlü bir histamin $\mathrm{H}_{2}$-reseptör antagonisti olan simetidin peptik ülser ve buna bağlı gastrointestinal bozuklukların tedavisinde kullanılmaktadır (4-8).

Simetidin etken maddesi taşıyan ve tablet formundaki müstahzarlar Türkiye'de Tagamet, Kıbrıs Türk Federe Devleti'nde ise Sigamet adı altında piyasada bulunmaktadır. Çalışmalar sonucu ortaya

Redaksiyona Verildiği Tarih: 14 Şubat 1983

Farmasötik Kimya Anabilim Dalı, Eczacılık Fakültesi, Ankara Üniversitesi. 
konulan Nükleer Manyetik Rezonans Spektroskopisi ile miktar tayini yöntemi hem laboratuvarımızda hazırlanan ve sadece simetidin ihtiva eden tablet, hem de piyasadan temin edilen ve yukarıda adı geçen müstahzarlara uygulanmıştır. Böylece, piyasada bulunan tablet formlarının taşıdı̆̆ı yardımcı maddelerin miktar tayinini etkileyip etkilemediği de araştırılmıştır. Gerek alınan spektrumlar, gerekse miktar tayini sonuçları bu bileşiklerin miktar tayinini etkilemediğini göstermiştir.

Simetidin'in dimetilsulfoksit- $\mathrm{d}_{6}$ içinde çekilen NMR spektrumunda (Spektrum: 1), $2.23 \delta$ ppm de imidazol halkasına bağlı metil protonlar $(3 \mathrm{H}, \mathrm{s}), 2.43-3.00 \delta \mathrm{ppm}$ de yan zincirdeki azot atomuna bağl1 metil ve $-\mathrm{S}-\mathrm{C} \mathrm{H}_{2}-\mathrm{C} \mathrm{H}_{2}-\mathrm{N}$ zincirinin kükürt atomuna bağlı metilen protonlar $1(5 \mathrm{H}, \mathrm{m}), 3.30-3.70 \delta \mathrm{ppm}$ de azot atomuna bağlı metilen protonları $(2 \mathrm{H}, \mathrm{m}), 3.82 \delta \mathrm{ppm}$ de imidazol halkasına bağlı metilen protonları $(2 \mathrm{H}, \mathrm{s}), 7.77 \delta \mathrm{ppm}$ de imidazol halkasinın protonu $(1 \mathrm{H}, \mathrm{s}), 7.50$ ve $12.40 \mathrm{ppm}$ de azot atomlarına bağlı protonlar $2 \mathrm{H}+1 \mathrm{H}, \mathrm{s})$ görülmektedir.

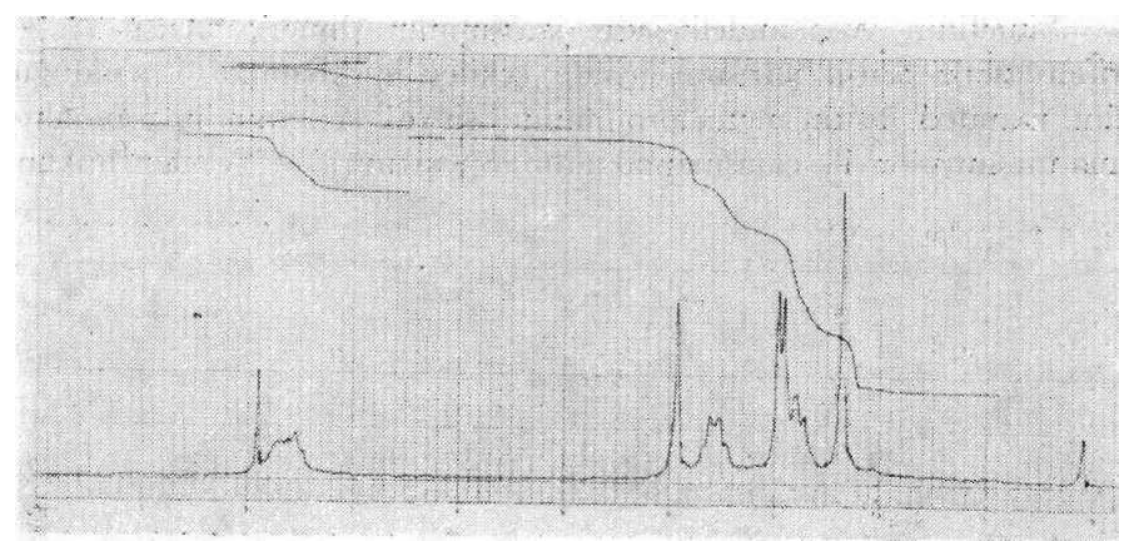

Spektr. 1. Simetidin'in $90 \mathrm{MHz}$ NMR Spektrumu.

Ortama birkaç damla trifloroasetik asit katıldı̆̆ında ise bu bileşiğin paramanyetik etkisi nedeniyle sinyaller değişik oranlarda olmak üzere daha düşük alana yani yüksek $\delta$ ppm değerlerine kaymaktadir (Spektrum: 2). 


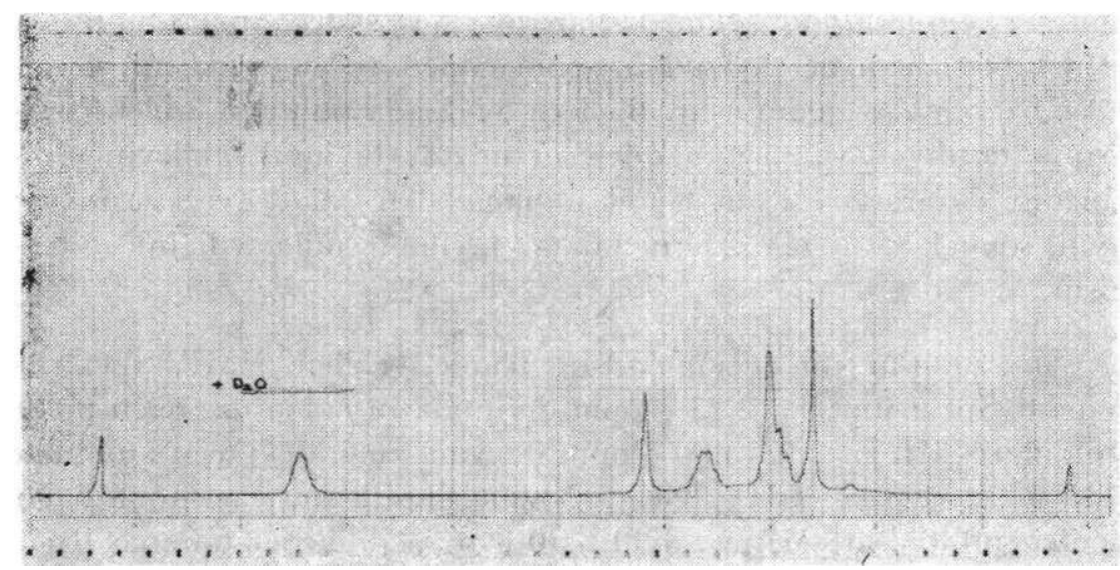

Spektr. 2. Simetidin'in DMSO- $\mathrm{d}_{6}+$ trifloroasetik asit içindeki $90 \mathrm{MHz}$ N MR spektrumu.

Miktar tayini yönteminde standart bileşik olarak mandelik asit kullanılmıştır. Bu bileşiğin spektrumu daha önce yapılan çalışmada verilmiştir (3).

* Simetidin ve mandelik asit karışımının dimetilsulfoksit-d 6 ve trifloroasetik asit-d karışımı içinde çekilen spektrumda, görüldüğü gibi, mandelik asitin metin protonunun sinyali simetidin'in protonlarına ait sinyaller ile çakışmamaktadır (Spektrum: 3). Yapılan miktar

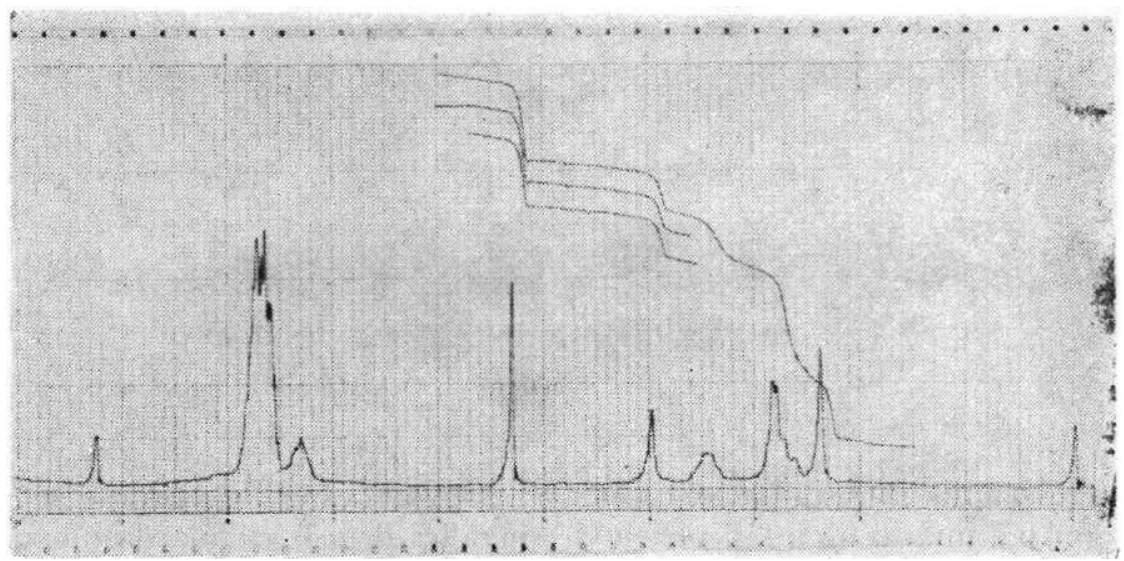

Spektr. 3. Simetidin ve mandelik asit karışımının DMSO-d ${ }_{6}$ ve TFA-d içindeki $90 \mathrm{MHz}$ NMR Spektrumu. 
tayininde mandelik asitin metin protonuna ait sinyal ile simetidin'in imidazol halkasına bağlı metilen sinyali kullanılmıştır. Ayrıca, simetidin'in $2.40 \delta \mathrm{ppm}$ civarında görülen metil protonlarına ait sinyal çözücünün sinyali ile karışmadı̆̆ından kullanılabilmektedir.

\section{YÖNTEM}

20 adet simetidin tableti tam olarak tartılır ve bir havanda ince toz haline getirilir. Tozdan $60 \mathrm{mg}$ civarında simetidin'e tekabül eden miktar tam olarak tartılır ve bir santrifüj tüpü içine konur. Üzerine $100 \mathrm{mg}$ civarında tam tartılmış mandelik asit ilave edilir. Karışıma, 1 ml dimetilsulfoksit- $d_{6}$ ve 3-4 damla trifloroasetik asid-d konur, iyice karıştırılır ve santrifüje edilir. Santrifüj tüpünün üst kısmındaki berrak çözeltiden ucuna pamuk takılmış bir pastör pipeti yardımıyla 0.4 ml civarında alınır ve N M R tüpüne konur. Karışımın N M R spektrumu çekilir ve miktar tayininde kullanılacak sinyallerin integrali birçok kez alınır ve bu integrallerin $\mathrm{cm}$ cinsinden ortalama yükseklikleri bulunur.

\section{HESAPLAR}

Deney sonunda miktar tayininin yapılabilmesi için gerekli hesaplar daha önceki çalışmalarımızda verilmişti (1-3). Hesaplar literatürde verilen çalışmalardaki gibi yapılmaktadır.

Miktar tayini ayrıca susuz ortamda titrasyon yöntemi ile de yapılmıştır (9). Bu yöntemde toz edilen 20 tabletten $400 \mathrm{mg}$ simetidin'e tekabül eden miktar tam olarak tartılmış, $100 \mathrm{ml}$ buzlu asetik asit içinde çözüldükten sonra 2 damla kristal viyole çözeltisi varlığında $0.1 \mathrm{~N}$ perklorik asit çözeltisi ile titre edilmiştir. Ayrıca kör deney de yapılmıştır.

Nükleer Manyetik Rezonans Spektroskopisi yöntemi ve susuz ortamda titrasyonla yapilan miktar tayinlerinde yapilan 5 deneyle bulunan ortalama sonuçlar \% hataları ile birlikte Tablo: 1 de gösterilmektedir.

Tablo: 1 den anlaşılacağı üzere Nükleer Manyetik Rezonans Spektroskopisi yöntemi susuz ortamda titrasyon yöntemine nazaran daha hassastır ve sonuç daha kolay ve çabuk elde edilebilmektedir. 
Tablo 1: Simetidin'in NMR ve Susuz Ortamda Titrasyon Yöntemleriyle Yapılan Miktar Tayini Sonuçları.

\begin{tabular}{|c|c|c|c|c|c|}
\hline \multirow{2}{*}{ İlaç Adı } & \multirow{2}{*}{$\begin{array}{l}\text { Taşıdı̆̆ı Te- } \\
\text { orik Simeti- } \\
\text { din Miktarı } \\
\text { (mg) }\end{array}$} & \multicolumn{2}{|c|}{ NMR Yöntemi } & \multicolumn{2}{|c|}{$\begin{array}{l}\text { Susuz Ortamda } \\
\text { Titrasyon Yöntemi }\end{array}$} \\
\hline & & $\begin{array}{l}\text { Bulunan } \\
(\mathrm{mg})\end{array}$ & $\%$ Hata & $\begin{array}{c}\text { Bulunan } \\
\text { (mg) }\end{array}$ & $\%$ Hata \\
\hline $\begin{array}{l}\text { Lab.da hazırlanan } \\
\text { ve saf simetidin ih- } \\
\text { tiva eden tablet } \\
\text { Tagamet (Fako) } \\
\text { Sigamet (ICP) }\end{array}$ & $\begin{array}{l}200 \\
200 \\
200\end{array}$ & $\begin{array}{l}199.6 \\
199.6 \\
199.0\end{array}$ & $\begin{array}{ll}\% & 0.2 \\
\% & 0.2 \\
\% & 0.5 \\
\end{array}$ & $\begin{array}{l}193.0 \\
194.2 \\
191.0\end{array}$ & $\begin{array}{l}3.5 \\
2.9 \\
4.5\end{array}$ \\
\hline
\end{tabular}

Susuz ortamda titrasyon yönteminde gerek perklorik asit çözeltisinin ayarlanmasında, gerek bileşiğin çözeltisinin titrasyonunda yapılacak hatalar sonuçta önemli değişiklikler meydana getirmektedir. Nükleer Manyetik Rezonans yönteminde ise kişisel hatalar sonuçta önemli bir değişikliğe sebep olmamaktadır.

\section{ÖZET}

$\mathrm{Bu}$ çalışmada, kompetitif bir histamin $\mathrm{H}_{2}$-reseptörü antagonisti olan simetidin'in tablet formlarmdaki miktarının tayini için Nükleer Manyetik Rezonans Spektroskopisi yardımıla yeni bir yöntem ortaya konulmuş ve yöntem piyasada bulunan preparatlara uygulanmıştır. Çalışmada ayrıca, ortaya konulan yöntem, susuz ortamda titrasyonla miktar tayini yöntemi ile sonuçları bakımından karşılaştırılmıştır.

\section{SUMMARY}

In this research, a new NMR spectroscopic determination of cimetidine, a specific competitive histamine $\mathrm{H}_{2}$-receptor antagonist, has been realized and the method is applied to the commercial preparations. The results of the method has also been compared with those obtained from the titration in none-aquous media.

\section{LİTERATÜR}

1- Noyanalpan, N., Özden, T.: J. Fac. Pharm. Ankara 7, 96 (1977).

2- Noyanalpan, N., Özden, T.: J. Fac. Pharm. Ankara, 7, 189 (1977).

3- Özden, S., Özden, T., Yalçın, L, Noyanalpan, N.: FABAD, J. Pharm. Sci., 8, 142-149 1983 
4- Brimblecombe, V., Duncan, W.A.M., Durant, G.J., Emmett, J-C., Ganellin, C.R., Parsons, M.E.,: J. Int. Med. Res., 3, 86 (1975).

5 - Haggle, S.J., Fermont, D.J., Wyllie, J.H.: Lancet, 1, 983 (1976).

6- Pounder, R.E., Hunt, R.H., Stekelman, M., Milton-Thompson, G.J., Misiewicz, J.J.: Lancet, 1, 983 (1976).

7- Bodemar, G., Walan, A.: Lancet, 2, 161 (1976).

8- Blackwood, W.S., Mandgal, D.P., Pickard, R.G., Lawrenc, D., Northfield, T.C.: Lancet, 2, 174 (1976).

9- Kajfez, F., Lisini, A., Toso, R., Belin, B., Sunjic, V., Christofis, O,: Acta Pharm. Jugoslav., 27. 199 (1977). 